to the official preparatory process and, in twelve locations around the world, will bring representatives of the Preparatory Committee to the people to listen and to learn of their concerns and expectations for UNCED.

Network' 92, a monthly news bulletin will report, in hard copy and electronic format, on plans and strategies that are being put into place by members of the independent sectors, governments, and international institutions. To support and enable the Centre to deliver these programmes, a network of eight regional focal points will be established with the cooperation of the Centre's regional Working Partners.
Third and finally, the Centre will continue, and aspire to strengthen, its efforts to stimulate dialogue on sustainable development through the Brundtland Bulletin and its core information programme.

WARREN H. LINDNER, Executive Director
Centre for Our Common Future
Palais Wilson
52 Rue des Pâquis
1201 Geneva
Switzerland.
Centre for Our Common Future 1201 Geneva Switzerland.

\title{
Global Environmental Conservation: Some General Aspects*
}

\section{Glimmerings of Hope}

A few years ago many of the older among us were thinking, and even saying publicly, that our world was in a terrible state and getting markedly worse. The basic reason for this gloom, which in some minds amounted to despondency, and which engendered such distressing works as the late Gordon Rattray Taylor's The Doomsday $B o o k$, was the ever-increasing numbers and profligacy of the human species. Egged on by tragic religious and other misleadership, and by poverty and ignorance not only in the Third World, humans, collectively, seemed to be insatiable in 'strangling our Earth', 'gobbling up irreplaceable raw materials', polluting air, soil, and water, and in generally threatening the future of our unique planet Earth or at least the life which makes it unique. Now however, there are some bright glimmerings, or better, of hope that we can avoid the abyss of planetary destruction, and in time even improve the general situation of Man and Nature. For this I believe we should set our chief hopes on, and support and encourage in every possible way, the main world bodies in the environmental/conservational movement, namely, IUCN (recently renamed the World Conservation Union), and UNEP (the United Nations Environment Programme). There are of course many others, but these two stand out for their clear and latterly unswerving leadership.

\section{Environmental Movements Improving Prospects}

Basic to this improving prospect is, I think, the widening influence of the environmental movement, which had emerged in part because more and more enlightened and thinking people, ever-more-widely in the world, had come to realize that planet Earth - at least as we know it and glory in its life - could be gravely threatened, even as regards its future survival in anything like its present form. With this realization came fear that, if certain things were not done and actions taken very soon, the worst would happen. Fear leads naturally to action for avoidance, and although this commonly needs to be on a more-or-less global scale, with the increasing realization that our world is one - that everything we do, even as individuals, can affect it in however infinitesimally small a way - there have come more and more remedial actions, in actuality or at least prospect. Very widely these have taken one or another form of conservation - of raw materials, of special areas, of disappearing biota, and of the specific amenities of our life.

* Some remarks made at the opening session of the (first) International Conference on the Conservation and Management of Rivers, held at the University of York, England, during 10-13 September 1990 - see page 376 of our preceding volume.
Ideally, as a biologist, one would like to see most natural features preserved in their 'original' form and pristine state, though clearly the time is long-past when this can be done at all widely. But is this necessarily so very sad? Are not numerous artificial, Man-made habitats, for example, more attractive aesthetically and productive of maintained biodiversity than their natural predecessors or counterparts? The answer is clearly in the affirmative, and for the benefit of Man and Nature. Think of Japanese and our own delightful gardens and contrived ecosystems; also note that, after nearly twenty years since the concrete jungle in which we live and work in Switzerland on the outskirts of Geneva was built and frightened them away after the first very few years, Nightingales (Luscinia megarhynchos) returned last spring to the too-narrow-for-nesting thickets alongside it, and regaled us nightly for the better part of a month. And as the seasons pass, we are entertained by a gratifying range and at times abundance of other bird-life.

When we come to consider freshwater habitats, however, their ecology and amenities are very different according to whether they are static or flowing. Of course there are all manner of 'grey' in-betweens; but in general the static bodies - including Man-made lakes and ponds - can be every bit as attractive biologically and aesthetically as their natural counterparts, and with due planning and planting, a good deal more so. But with flowing streams and rivers, the greatest caution and foresight have to be exercised in altering them, as Dr E. Barton Worthington will shortly indicate from the annals of his enviably wide and prolonged experience.

\section{Need for Further Evolution of Homo}

But first I would like to propound the desirability of, if not venture as yet to launch, a campaign for the further evolution of Mankind - our unique species which has in many ways come so much farther in its evolution than any other living creature, that I for one cannot believe it could not be persuaded and guided to take one further vital step. That step should be from the present situation in which people think mainly of their own selfish interests and pursuits, to one in which they think and act first and foremost for the good and future of the world as a whole, and especially for the welfare of The Biosphere which, extending so far down in Earth's depths and up in its attendant atmosphere as any form of life exists naturally, constitutes practically our entire life-support. If only such welfare were the primary and abiding concern of people sufficiently widely in the world, they would surely convert enough of the others to the imperative of saving The Biosphere and see to it that the right actions 
were taken to that paramount end to which all others should surely be subservient.

Necessary actions or at least directions are now so well known that I need not repeat them before an enlightened scientific audience. Suffice it to say that, were it not for the indulgence and profligacy of which we are all to some extent guilty, we would not be threatening increasingly the availability of sufficient space and raw materials to support the desirable numbers of humans inhabiting the Earth, we would not be threatening the stratospheric ozone shield and stability of climates, we would not be threatening the seas and limited fresh waters increasingly with pollution, or the soils and forests with salinity and acidity: all could be arranged to save our world.

So let us look to some such campaign as the further evolution of Mankind - to a new subspecies or at least forma or other taxon that we may dream of as Homo supersapiens - preferably by persuasive demonstration, failing that by legal processes, or even by genetic manipulation or yet other means, and regardless of how difficult and costly those means might have to be.

Already we have had in being for some years past the World Council For The Biosphere, of which Sir John Burnett is Executive Secretary. He will be well known to many of you as the recent Principal and Vice-Chancellor of the University of Edinburgh who was, until earlier this year, Acting Chairman of the Nature Conservancy Council; and if no major body takes up such a challenging theme beforehand, I plan to propose it to the World Council For The Biosphere for active promotion at latest by the time I relinquish the founding chairmanship of that body by statute in the Autumn of 1992 .

NichOlas POLUnIN

\section{Forests in the European USSR}

The European part of the USSR essentially consists of the rolling East European plain, less than $200 \mathrm{~m}$ above sea-level, which is bordered on practically all sides by mountains: the Caucasus and Crimean Mountains to the south, the Carpathians to the west, the Urals to the east, and the Khibiny Mountains to the north. Thirty-four per cent (192.3 million hectares) of the European USSR is covered by forests. The average coverage currently ranges from $58 \%$ of land in the north to only $2-3 \%$ in the southern regions of the Ukraine and Russia. Seven vegetation zones succeed one another from north to south of the country: Arctic 'desert', tundra, forest tundra, mixed forest, forest steppe, semi-desert, and subtropical vegetation of various types.

Typical of the northern part of the forest zone are evergreen coniferous fir (Abies), pine (Pinus) and spruce (Picea) forests, though larches (Larix) are widespread in the eastern part. Mixed forests of similar coniferous content but also broad-leafed trees such as species of birch (Betula), aspen (Populus), alder (Alnus), oak ( Quercus), linden $=$ lime $($ Tilia $)$, hornbeam $($ Carpinus $)$, ash (Fraxinus), beech (Fagus), maple (Acer), and elm (Ulmus), characterize the Southern part (stretching from the Carpathian Mountains to the Volga and the southern Urals).

The forest steppe stretches in a continuous narrow strip from west to east. Its vegetation consists of alternating small forests of Black Locust (Robinia pseudacacia), and/or oak, maple, elm, etc., species. Steppe vegetation on the lower slopes of the Caucasus gives way higher up to broad-leafed forests mainly of oak and beech, followed still higher by coniferous mountain forest (including Nordmann Fir [Abies nordmanniana] and Oriental Spruce [Picea orientalis]).

Subtropical wetland vegetation occurs in the Kolkhida lowlands on the south-east coast of the Black Sea and in the Lenkoran lowland on the south-west coast of the Caspian Sea: broad-leafed forests of Black Alder (Alnus nigra), various oaks, European Hornbeam (Carpinus betulus), water-elm, and wing-nut, with an abundance of creepers and various shrubby evergreens.

\section{Severe Threats}

Timber reserves in the forests of the European USSR total 24.3 thousand million $\mathrm{m}^{3}$. Stocks of the various main species are reported to increase annually by some
333 million $\mathrm{m}^{3}$. Last year (1990) the total volume of wood stocked, excluding 'improvement felling', was 191.9 million $\mathrm{m}^{3}, 90 \%$ of the felling being carried out in the coniferous forests.

Forests in the northern and northeastern parts of the European USSR have been considerably depleted by clear-felling. The use of heavy machinery compacts the soil and affects the water system. Moreover, industry and 'acid rain' are proving increasingly harmful. Damage to forests in the Kola Peninsula, some Baltic regions, the Urals, and areas around major towns and industrial centres, has been extensive. The effects of 'acid rain' in the main territory are, however, relatively slight.

Following the nuclear disaster at Chernobyl, 3.5 million hectares of forest in the Ukraine, Byelorussia, and the Russian Republic, have suffered varying degrees of pollution. 47,400 hectares of forest suffered dieback in the European USSR last year, largely as a result of changes in the water system, unfavourable weather conditions (drought, humidity, winds, etc.), industrial waste, and damage caused by insects, wild ungulates, rodents, and cryptogamic plant diseases.

Centres of Tortrix viridana and other accompanying Tortricidae have been recorded over an area of 533,500 hectares. Dendrolimus pini, Lymantria monacha, Bupalus piniaria, and other harmful parasites, have also been reported. Root-rot has been recorded over 218,000 hectares. Major concentrations of wood parasites are found close to large towns and industrial centres.

There are 41 State forest conservation stations in the European USSR. In 1989, various measures were taken to control pest populations over 955,700 hectares, i.e. $1 \%$ of the total forest area in the European USSR. Biological forest conservation methods accounted for $71 \%$ of these measures in terms of financial expenditure.

Recently, new parasites have emerged against which no biological treatment is yet available, i.e. the ash weevil in Moldavia, the juniper moth in the Crimea and Krasnodar, and the oak moth which is very widespread in central Ukraine.

\section{Reafforestation}

The European USSR has extensive experience in reafforestation, with some 2 million hectares being replanted every year; of this, some $95 \%$ involves coniferous species. Productive reafforestation is widely 